\title{
Factors influencing customer preference of cardless technology over the card for cash withdrawals: an extended technology acceptance model
}

\author{
Bindu K. Nambiar ${ }^{1} \cdot$ Kartikeya Bolar $^{2}$ (])
}

Received: 5 January 2021 / Revised: 30 June 2021 / Accepted: 10 January 2022 / Published online: 27 January 2022

(c) The Author(s) 2022

\begin{abstract}
It can seem paradoxical that someone who evades the use of a debit card still wants access to cash and is willing to use their mobile device at an ATM. The cardless cash technology delivers a solution that is an improvement over the traditional form of cash delivery. This study explores the influential factors that affect the preference of cardless cash over cards. A crosssectional survey was utilised to collect both data through a self-administered questionnaire. A total of 521 bank customers from one of the largest banks in India participated in the study employing a convenience sampling technique. The responses were analysed using a predictive analytics approach with various statistical and data mining techniques. Customers preferred cardless cash because of its usefulness over the Card rather than perceived ease of use, customer trust, or perceived security. This paper contributes to the banking world's ways of pre-stage access to cash, reducing customer contact at ATMs. It highlights the main factors that influence customer's preference towards using cardless cash technology at ATMs, helping banks spread the newest technology used to provide a financial instrument that has been here for centuries—cash.
\end{abstract}

Keywords Cardless cash · Automated teller machine (ATM) · TAM · Banking · Customer preference

\section{Introduction}

Banking services are undergoing significant shifts due to a wide variety of factors. How the banks adapt to these changes is the key to staying relevant and stimulating growth. The imperative here is to facilitate the customers' desire for financial independence through innovative and imaginative products and processes, appealing to the customers' dreams and aspirations. Banks have witnessed headwinds accentuated by the ever-evolving market dynamics. However, they were also hugely supported by tailwinds like digitisation and digitalisation. These continuous upheavals, amplified by the domestic and global scenarios, have pushed the banks to provide a robust platform and multiple channels to deliver the best customer experience.

Kartikeya Bolar

kartikeya.bolar@manipal.edu

1 State Bank Institute of Consumer Banking, Hyderabad, India

2 T A Pai Management Institute, Manipal Academy of Higher Education, Manipal, India
Customer experience and satisfaction have a considerable impact on the bank's financial performance (Mbama \& Ezepue, 2018), and bracing innovations in enhancing customer experience will genuinely shape the future of banking. The forces that reshape the banking landscape begin with the rapid evolution of customer demands (Kumar \& Balaramachandran, 2018) that elevate the benchmark for exceptional customer experience. Secondly, emerging fintech and digital platforms drive the disruptive innovative solutions compelling the traditional banks into the most incredible opportunity (Gomber et al., 2018). Banking has been identified as one of the business sectors that has been most impacted by the internet's spread (Flavian et al., 2006). However, it is also a window of unfulfilled opportunities to define a point of difference concerning their fintech competitors, leverage their channel, and deliver and meet the unique customer needs in an emotionally significant way (Zachariadis \& Ozcan, 2017). Additionally, the entry of multiple players is also questioning the hegemony of brick-andmortar banks unravelling new paths and pushing banks to align their approach with the current evolution of customer expectations. 
Along with the banking system, the customer domain has also undergone a sea change. Today's customers are very different from their counterparts of the past decades. They have become highly tech-savvy and more demanding. They have an enhanced understanding of the various advances in technology. They tend to adopt those technologies early on, some of which are disruptive to the hitherto seen banking landscape. They probe the full spectrum of banking channels to see what suits them better. They visit bank branches less frequently due to the rapid rise of information and communication technologies, wireless technologies, and mobile devices and do most of their banking online (Singh \& Srivastava, 2020)

With such a high level of technology adoption, banks need to account for the fact that customers have a high degree of anxiety (Shen et al., 2010). Traditionally, banking is positioned to instil trust (Yousefi \& Nasiripour, 2015). However, considering customers' growing needs through the banker's lens of service and experience, alleviating customer anxieties may be a significant vulnerability for technologybased high anxiety settings like banks (Shell \& Buell, 2019).

The present-era customers may have a substantial amount of discretionary income and are probably in their wealth creation phase in their lives. Hence, it offers an excellent opportunity for banks to capitalise and build profitable longterm relationships. Nevertheless, banking relationships are involved in transactions-based activities more (Arnoud et al. 2011). Financial providers need to concentrate on spinning up and removing the friction points in the buyer's journey (KPMG, 2018). Banks need to provide a high degree of convenience and access to financial products (Yiu et al. 2007). Thus, the critical priorities for banks need to be building relationships and removing friction points in the customer journey. Innovations are happening across the globe to address these priorities. One such innovation is the application of cardless cash technology to withdraw money from ATMs without card use. One reason that prompted cardless cash technology is the rising number of ATM frauds (Agidi, 2018; Ali et al., 2021).

Empays, India's authorised payment system, teamed with Mastercard to launch 40,000 ATMs that accept this payment scheme (Mastercard press release, 2020). It employs SMS technology to allow cash withdrawals from participating ATMs without the need for a card. State Bank piloted the concept in India with YONO Cash, and almost all their ATMs are configured for cardless withdrawals. According to TRAI's most recent survey, India has 1.16 billion wireless or mobile telecom users, out of a population of 1.3-1.4 billion people. Since all Debit/Credit/ATM cardholders will be having a mobile number tagged to the Card, this makes the potential for a cardless payment system unbelievably vast.

Cardless ATM is a technological innovation that allows customers to make cash transactions from their accounts using a simple mobile application rather than a physical card at the ATMs. When a customer wants to withdraw money from a cardless ATM, the app produces an authentication key in a numeric code. By entering the PIN and password correctly, the ATM will process the transaction and disburse cash without a physical card. Cardless ATMs can enhance customer service by allowing customers to withdraw cash more quickly and effectively while lowering transaction costs and also not charged a fee for the cash withdrawals from the bank's ATMs.

Furthermore, there will no longer be a concern of losing the Card or missing their PIN (Phothikitti, 2020). Banks face the critical risks of credibility and reputation when hackers tear into the machines in different ways (Lim et al., 2017). Physical cards get cloned by professionals, and replacing magnetic strip cards with chip-based cards has not reduced card-related fraud. Such actions lead to repercussions from the regulator and numerous fraud-related RTI queries and litigations. Accordingly, cardless withdrawals avoid the risk of fraud unless the cardholder is complicit.

However, despite intensive social media and direct campaigns, cardless cash technology is yet to get the required momentum. Customers hesitate to use this technology because of the associated risks and the lack of knowledge of the benefits of cardless cash technology. The perceived risks may be overwhelming compared to the traditional method of banking. Customer's judgements about the capabilities (such as required knowledge, skill, and self-efficacy) to use the technology may impact their intentions since cardless cash technology may appear as a form of complicated technology (Ali et al., 2021).

Based on the above premise, an empirical study of customers' preference for cardless cash withdrawals at the ATMs over cards was attempted, considering the importance of ATMs in providing customer delight and the role that mobile phones play in their lives. There are many customer complaints about ATM fraud, and the entire system spends a significant amount of resources to address and resolve these issues. These critical factors spurred a study to see if increased perceived security, trust, ease of use, and usefulness of cardless cash technology led to a higher likelihood of preferring cardless cash technology over card transactions.

This paper's coverage is as follows: Sect. "Literature review" provides a literature review, which leads to the development of the hypothesis and research model in Sect. "Research model and hypotheses". We describe data collection and research methodology in Sect. "Data collection and methodology". We provide data analysis and interpretations in Sect. "Data analysis and interpretation", which are further discussed in Sect. "Discussion". Section "Conclusion" presents conclusions and some implications for practitioners and researchers. 


\section{Literature review}

Can we claim cash could become obsolete (Mercadante, 2020) when 500 billion banknotes circulating globally and physical cash accounted for 9.6\% of GDP in 2018, up from 8.1 per cent in 2011 (World Cash Report, 2018)? However, India's currency circulation fell to 13.35 trillion rupees after the demonetisation of 500 and 1000 rupee notes in 2016. Nonetheless, it swiftly recovered to a level of 28 trillion rupees (Statista, 2021). Similarly, progress towards a cashless society has been gradual in other geographies, such as Europe (Auer et al. 2020). In 2015, the Eurozone's economy accounted for $9 \%$ of global GDP, while the US' economy accounted for 7\%. Banknotes and coins account for up 3\% of the Swedish economy, despite the country's near-cashless status (Batiz-Lazo et al. 2016). As a result, despite massive efforts to digitise data and transactions, cash, the complicated currency, appears to reign supreme.

\section{Emergence of electronic modes of payment}

Technological advancements and the ever-increasing mobile density have increased manifold the scope of digital payment in the mobile commerce industry (Au \& Kauffman, 2008). Digital payment is a transaction made on digital platforms. Here, the sender and the recipient both use digital modes for paying and accepting payments. It is also called payment by electronic means. In India, digital payments have been growing at an exponential rate, and with the country's increasing internet and mobile penetration, the government is prepared to see a massive surge in digital payment use in the coming years (Singh \& Rana, 2017). The different digital/electronic payment modes include credit card/debit card payments, mobile wallets, Unstructured Supplementary Service Data (USSD) channel, Aadhar Enabled Payment System (AEPS), United Payments Interface (UPI), internet banking, mobile banking, and Micro ATMs.

One of the electronic payment methods is the use of cards has increased during the last two decades. The government invested in strengthening the infrastructure for accepting cards at various merchant locations as part of demonetisation. Several programmes were available, including cash back, no transaction costs up to a specific amount, to further assist with digital transactions (Bhakta, 2017). With over 3.5 million ATMs worldwide thus, cards became one of the most popular ways for customers to interact physically and remotely with their bank. Customers could go up to an ATM and do a variety of financial transactions. This way, customers recognised that technology was capable of far more than simply dispensing cash.
The ever-evolving technological innovations enabled the payment landscape to expand beyond cash and ATMs quickly. The introduction of initiatives like the electronic payment system allowed customers greater leverage over managing cash (Deloitte, 2015). This move also considerably reduced banks' time spent on manual processing (Bahillo et al. 2016) and reconciling transactions (Guo \& Liang, 2016), saving considerable costs (Gomber et al. 2016). More importantly, the technological platforms made payment processes easy and convenient for customers and provided real-time information for analysis to the banks on an ongoing basis (Capgemini, 2013). Furthermore, a boom in Fintech firms (KPMG \& NASSCOM, 2016) and government digitisation programmes (Kaka et al., 2019) also acted as catalysts.

Additionally, through technology-led payment platforms, payment happens intuitively in the background at the end of every purchase. Customers, therefore, are prompted to use these platforms more frequently as recurring payments lead to higher rewards and savings. Consequently, a deeply integrated technology-based and easy-to-operate platform are needed to help banks grow in value, recovering all lending money while providing free payments. Nonetheless, each bank also needs to ensure that the investment in technologybased payment infrastructure is recovered as soon as possible (Ngumi, 2014). This infusion of technology should delight customers (Bitner et al. 2000), increasing their willingness and ability to adapt and use technology more (Shaw, 2014), thereby validating the organisation's investment.

\section{Cash versus electronic mode of payment}

While there appears to be no reliable calculation for cash consumption, the Reserve Bank of India (2020) has listed two indicators to measure. They are the Currency value in Circulation (CIC) relative to Gross Domestic Product (GDP) and ATM withdrawals. CIC grew at a compounded annual growth rate of 10.2 per cent between 2014-15 and 2018-19, implying cash preference. During those years, the second measure, cash withdrawals from ATMs, has also increased, and the proportion of cash withdrawals to GDP has been consistent at $17 \%$. However, the ATMs experienced slower growth, with a CAGR of $4 \%$ over those years and the increase in cash usage also slowed down compared to digital payment transactions. Cash usage grew at a CAGR of $9 \%$ in volume and $10 \%$ in value, whereas digital payments grew at a CAGR of $61 \%$ in volume and $19 \%$ in value (RBI, 2020). While this comparison points to a positive shift towards digitisation, cash remains a convenient transaction mode for citizens living in semi-urban and rural areas (Mohite et al., 2021).

ATMs are a vital touchpoint that serves as an extension of the bank branch, facilitating financial inclusion and 
providing easy access to cash for withdrawals supporting the government's economic relief initiatives to the less privileged. Most government payments are through DBT (Direct Benefit Transfer), which entails the usage of cards, and optimally pushes for enhanced financial literacy and inclusion. Unfortunately, ATM penetration in India in terms of population is among the lowest among emerging markets (RBI, 2019), with less than one-fifth of ATMs deployed in rural areas (Irani, 2021). However, there is visible engagement by the government, regulators, and banks to increase ATM installation in remote areas. One of such decisions by the Reserve Bank of India to hike the interchange fees will increase ATMs' penetration, making it attractive for banks to install more ATMs in more geographies.

\section{Conception of cardless cash technology}

With the growth of the ATM network, banks and customers alike were forced to deal with new problems they did not cause, such as skimming, hacking, cloning, and phishing of their cards. As a result of such instances, the notion of cardless ATMs was conceived. ATMs incorporated advanced technologies such as cardless and contactless cash withdrawals, biometric fingerprint, or iris-based access. This cardless option enabled customers to access cash until a lost, stolen, or infringed Card is replaced, potentially reducing the need for express delivery of the replacement card. Cardless cash technology is mobile-driven access to cash, without a card, a significant step towards anywhere and anytime money. Customers also appear comfortable when they need not carry cards for withdrawals. Hence, cardless solutions most appropriately address the customers' desire for convenience. Yet, customers are also concerned with security (Singh \& Srivastava, 2020), so tokenisation is included as an additional layer of protection for ATM access (Finserv, 2016). As a result, cardless cash technology provides an excellent option for providing customers with increased security.

\section{Characteristics of cardless technology}

Cardless technology enables banked, under-banked, or unbanked customers to transfer and withdraw funds using electronic devices over a wireless network (Karthikeyan, 2012). It allows account holders to withdraw money from their accounts without using a card (Istrate, 2014). Besides that, this feature also offers access to banking facilities, such as transferring funds, to individuals who do not have an account with the bank (Moodley, 2011; Kinsman, 2019), allowing them to withdraw cash without a card (Innova, 2015). All these transactions are carried out using customer's personal information.

\section{Benefits of cardless cash technology}

ATMs using cards currently do not provide adequate protection. If a person secures a debit card and its PIN, the account can be misused. However, cardless ATMs offer a more robust verification procedure to guarantee that the correct person accesses an account. Yet again, the cardless cash technology improves protection by removing the risk of 'shoulder surfing' and card-skimming. This feature eliminates amount details inserted into ATMs and guarantees the non-storage of a customer's data on the mobile device and all the other critical financial credentials with which the customer carries out a transaction (Bhosale \& Sawant, 2012). As customers retain familiar mobile user interfaces, it simplifies how users can perform a cardless cash technology (Asfour \& Haddad, 2014). Its ability to carry out transactions without a branch or waiting in the queue makes the cardless cash technology convenient for customers (Johnson, 2014). In addition to customer convenience, self-service electronic platforms such as ATMs also minimise the costs of services and operations (David-West, 2006). The transaction costs associated with cardless cash technology are comparatively lower than those associated with card transactions due to lower ATM withdrawal, recurring payment fees, and transfers fees. Banks can avoid, in this way, grievance related to cards (Bhosale \& Sawant, 2012). Again, the cardless cash technology has additional security measures, such as computer-generated codes sent via a short message service (SMS) on a secure network as part of a two-code authentication system (Istrate, 2014).

\section{Digital/mobile/E-wallet versus cardless cash}

Digital wallets facilitate online shopping (PayPal), transferring funds between friends (Venmo), or paying at the gas station (Apple Pay) by phone. A mobile wallet is one that customers access via an app on a mobile device (usually a phone or wearable) using "tap to pay" in a store while checking out. It is a simple alternative to paying with cash or carrying around a bevvy of physical cards. Customers have store boarding passes and concert tickets in mobile wallets. They are safe to use because payment information is over NFC waves. The systems encrypt data in the form of a "token". The token does not expose details of the actual account that might otherwise be compromised. Since a mobile wallet requires a passcode, fingerprint, or a face scan before the customer makes a payment, it is safer than credit cards or cash, which anyone can use if stolen. Therefore, the distinction between digital wallets and mobile wallets is that the customer can have a mobile wallet on a mobile device in an app, and a digital wallet is accessed through a desktop.

The difference between an E-wallet and a Digital Wallet/Mobile Wallet is that before any transaction (online or 
offline), E-Wallet enables the user to move and load currency into them, whereas digital wallet merely saves the user's card information for simple future transactions, with the funds remaining in the user's bank or card account.

Conversely, cardless technology helps users withdraw cash safely and efficiently at ATMs for daily use without using any card. For using cardless technology, the customer has to download the respective bank's application on the mobile. For instance, for ICICI Bank, customers need to download the mobile app on their smartphone from Play Store or App Store. After that, they select the 'services' option and select the cardless cash withdrawal option. After entering the amount, the customer generates a 4-digit temporary PIN, specifies an account number to debit the amount, and selects the submit button after confirming the details. The bank then sends an SMS with a unique code on the registered mobile phone, which the customer must save for future uses. Subsequently, the customer visits the specified bank ATM and makes a cardless withdrawal.

The advantage of using cardless cash technology is that the recipient need not have any bank account and still withdraw cash from any ATM across India without using the Card, using the details received through an SMS on a mobile device. Drawing money without a card can provide customers privacy and comfort as the technology is remote access and does not allow skimming or stealing of physical cards. Customers who have their mobile phones arrive at the ATM and withdraws money by keying the saved PIN sent via SMS. With this facility, a customer can transfer money instantly anywhere to anyone. All they need to do is to add a beneficiary's mobile number, name, and address.

\section{Research model and hypotheses}

The Technology Acceptance Model (TAM) proposed by Davis (1989) has been extensively used to measure the adoption of various technologies and technology-enabled services. According to Davis (1989), multiple factors influence the customer's decision to adopt or reject technology. Previous research reveals two significant determinants. First, "people are more likely to use or not use an application if they believe it would help them accomplish their work better" (Davis, 1989). This variable is referred to as "perceived usefulness" (P.U.) (Davis, 1989). Second, "people believe that if a technology is too difficult to use, they are less likely to embrace and use it, even if they think it is functional". This second measure is referred to as "perceived ease of use" (PEOU) (Davis, 1989).

The viability and robustness of TAM have been established and validated in different technology-based services domains decades ago since Davis (1989) introduced the model. As Poong et al. (2017) stated, the available literature
Table 1 Context and studies

\begin{tabular}{ll}
\hline Context & Studies \\
\hline Online ticket reservations & Gurit \& Siringoringo (2013) \\
Tele-banking & Sundarraj \& Wu (2005) \\
SMS banking & Amin \& Ramayah (2010) \\
Mobile phone credit cards & Amin (2008) \\
Mobile website & Zhou (2011) \\
Mobile payments & Hampshire (2017) \\
E-banking & Salimon et al. (2017) \\
E-payment & Teoh et al. (2013) \\
Online shopping & Gefen et al. (2003) \\
Mobile shopping & Chen et al. (2018) \\
\hline
\end{tabular}

significantly demonstrates the viability and robustness of TAM in technology adoption. Again, individuals and firms in both developed and developing economies around the globe have used TAM to predict the adoption and use of the latest technologies (Glavee-Geo et al., 2017). Legris et al. (2003) has also confirmed that TAM is the most significantly utilised model to predict the extent of technology adoption. However, Lee and Jun (2007) alleged that the TAM must have the ability to examine more factors affecting use intentions further than the usual two factors. Various research studies have also extended TAM on different technologies, especially in service industries (Hanafizadeh et al., 2014; Mehrad \& Mohammadi, 2016; Chitungo \& Munongo, 2013; Lee et al. 2011). Moreover, Shaikh \& Karjaluoto's (2015) findings reveal that existing literature on adopting technology in banking generally relies on TAM and its relevant modifications. These studies have modified and extended TAM to enhance its power of prediction and explanation in the arena of technology acceptance (Jayasingh et al. 2009). Again, Brown \& Venkatesh (2005) have termed TAM incomplete as it excludes economic, demographic, and external factors (Mehrad\& Mohammadi, 2016). Hence, existing studies have suggested supplementing TAM with additional variables to understand better and predict technology adoption (Liébana-Cabanillas et al. 2017).

Earlier studies of Amin et al. (2012), Anderson and Gerbing (1988), Bankole et al. (2011), Ramayah \& Suki (2006), and Venkatesh \& Morris (2000) have ascertained the prime factors of TAM (P.U. and PEOU)to be the most constructive elements in predicting adoption of information systems in different settings as indicated in Table 1

Yet again, Davis (1989) stated that TAM could be further supplemented and customised with external variables, which is the prime reason for its wider acceptance. Various research studies have extended TAM on different technological aspects, which have been adaptive to service industries, especially in banking (Moser, 2015). To add credence, King $\& \mathrm{He}$ (2006) conducted a meta-analysis of TAM, including 
Fig. 1 Theoretical framework

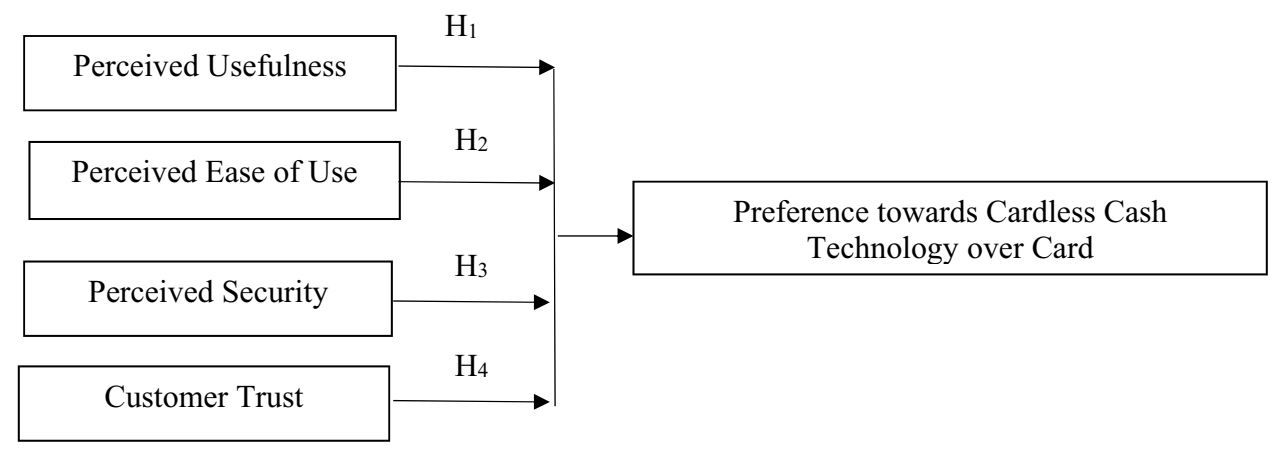

88 studies that utilised TAM in different settings. They termed the model as possibly the most powerful, versatile, and robust with highly reliable predictive capabilities in various contexts.

\section{Customer preference}

Customer preference refers to the predisposition of customers to choose (Howard \& Sheth, 1969), and customers who perceive that specific offerings are customised to satisfy their tastes are likely to use more (Moon \& Lee, 2014). Also, customised products based on customer preferences are considerably more likely to receive favourable responses (Franke et al., 2009). A series of recent studies emphasised that there should be a focus on customer preferences rather than on technology adoption to become customer-centric (Fogliatto et al., 2012). If there is a close fit between customer preferences and product/service features, it will lead to higher adoption (Simonson, 2005). Hence, determining how individuals perceive the fit between a product/service features and their personal preferences is critical (Franke et al., 2009).

In banking nowadays, customers pay for transactions with an increasing variety of payment methods. Past several decades, there has been a rising emergence of electronic payment mechanisms like credit cards, charge cards, and debit cards, in addition to traditional forms such as cash and cheques. A new wave of payment systems such as smart cards, memory cards, and online payments rose that eventually constituted a large proportion of all customer purchases (Marlin, 1998). Apart from strategic reasons such as maximising the transaction's perceived attractiveness, the choice of payment is also motivated by more straightforward considerations such as convenience, retailer acceptability, accessibility, and fee for usage (Loewenstein \& Prelec, 1998). Nonetheless, there is not much research on the proliferating spectrum of payment mechanisms' influence on customers' preferences or vice versa. Though some studies have compared conventional cash-based and card-based transactions, these studies found that cash-based payment is very significant in both physical form and amount. The implication is that how customers respond to cash-based and card-based payment mechanisms is different. This difference may affect customer's perceptions and choices (Soman, 2003). As discussed in the earlier sections, the cardless cash feature is revolutionary for its advantages. This feature results in the reduction of transaction time to half and minimisation of ATM system downtime. Moreover, studies from Lewin (1951) and Festinger (1957) indicate that choices between desirable yet completely contradictory alternatives would conflict as the options become similar. The exact inference may be plausible while comparing Card and cardless cash withdrawals.

The following research model (Fig. 1) is built on understanding the interrelationships between perceived ease of use, perceived usefulness, perceived security, and customer trust with a preference for a card or cardless technology for cash withdrawals.

\section{Perceived usefulness}

Davis introduced perceived usefulness as one of the TAM components (1989). It relates to how much a person believes that employing technology would help them perform better (Doll et al., 1998). A few researchers have examined the usefulness of technology-driven banking (Eriksson et al., 2005; Wang et al., 2003) and confirm that perceived usefulness substantially impacts technology-led banking (Amin et al., 2007; Tang et al. 2004). As a result, the following hypothesis is proposed:

H1 Perceived usefulness has a significant positive influence on the preference of cardless cash technology over the Card to withdraw cash.

\section{Perceived ease of use}

As defined by Davis (1989) and Venkatesh \& Davis (2000), perceived ease of use refers to how easy it is to use technology-led banking. Perceived ease of use is a person's judgement of the effort expended due to technology use (Davis, 1989). People's perceptions about technology usage may 
also be described as their belief that it will be free of mental stress and that they will not have to devote much of their time and effort (Raza et al. 2017). Applications that are clear and simple interfaces will encourage customers to try out technology-led banking channels (Singh \& Srivastava, 2020). Hence, the following hypothesis is proposed:

H2 Perceived ease of use has a significant positive influence on the preference of cardless cash technology over the Card to withdraw cash.

\section{Perceived security}

Offering banking services in the virtual environment is challenging (Mann \& Sahni, 2013). One of the most significant impediments to the adoption of technological innovation is security, and many studies suggest that firms that operate on the internet must first convince their customers about security (Mattila \& Mattila, 2005).

According to Chen and Zahedi (2016), security assures authentication, non-denial confidentiality, and data integrity when using technology-led banking. Generally, such transactions stand up susceptible to various attacks like phishing, viruses, and malware that prohibit customers' online operations. As Bansal and Zahedi (2014) stated, security concerns do get translated to the failure of the technology to safeguard transaction information. Hence, the hypothesis is formulated as:

H3 Perceived security has a significant positive influence on the preference of cardless cash technology over the Card to withdraw cash.

\section{Customer trust}

According to Dwyer et al. (1987), trust is essential for successful economic transactions. This aspect has since been integrated into customer relationship-building models by experts on customer decision-making. Rempel et al.'s (1985) seminal research describe trust as a generalised expectancy a customer bestows on the business's word, promise, or statement. For a customer, trust is particularly significant when the situation involves risk and uncertainty (Mayer et al., 1995). The nature of internet banking raises the value of trust, as there is no direct physical interaction between customer and banker (Yap et al., 2009). Trust is instrumental in generating goodness or profit. Banks with the increasing adoption of technology require a high level of trust over their security and privacy (Yauzafzai et al., 2007). More so, Reichheld and Schefter (2000) found that trust is an antecedent for technology adoption in internet-based services. Hence, the hypothesis is formulated as follows:
Table 2 Demographic variable sample composition $(n=521)$

\begin{tabular}{ll}
\hline Category & Frequency \\
\hline Gender : Female & $166(32 \%)$ \\
Gender : Male & $355(68 \%)$ \\
Marital Status & $372(71 \%)$ \\
$\quad$ :Married & \\
Marital Status & $149(29 \%)$ \\
$\quad$ : Single & \\
Age Group : Below & $50(10 \%)$ \\
$\quad$ 20 & \\
Age Group : 20-40 & $170(33 \%)$ \\
Age Group: 40-60 & $256(49 \%)$ \\
Age Group: Above & $45(8 \%)$ \\
$\quad$ 60 & \\
Prefer cardless & $429(82 \%)$ \\
Prefer card & $92(18 \%)$ \\
\hline
\end{tabular}

H4 Perceived trust has a significant positive influence on the preference of cardless cash technology over the Card to withdraw cash.

\section{Data collection and methodology}

We captured the responses from the customers of one of the largest public sector banks in India through a structured questionnaire after seeking permission from the bank and consent of the customer at the branch itself. Convenience sampling was used in this regard. This public sector bank has been one of the earliest banks to introduce cardless technology and therefore choosing this bank was appropriate. The questionnaire consists of the adapted scale items for the constructs, namely Perceived Usefulness (P.U.), Perceived Ease of Use (EOU), Customer Trust (TR.) and Perceived Security (SEC.). We also asked an additional question regarding the preference of cardless cash transactions over the Card. Table 2 below summarises the demographic profile of the respondents.

The questionnaire was developed by adapting the established scales to measure the Extended TAM constructs from (Davis, 1989), (Bansal and Zahedi, 2014) and (Chatterjee and Bolar, 2019). All the constructs considered in the study were measured on a five-point Likert scale $(1=$ "strongly disagree," and 5 "strongly agree"). A summary of items operationalising all the constructs is shown in Table 3.

We first carried out principal component analysis followed by the confirmatory factor analysis for the four constructs Perceived Ease of Use, Perceived Usefulness, Security, and Trust.

We then used the CRISP-DM (Cross-Industry Practices for Data Mining) methodology of Predictive Analytics to test the hypothesis. We used this not only for the explanation purpose but also for checking the research model's predictive 
Table 3 Summary of variables and respective questionnaire items

\begin{tabular}{lll}
\hline Item code & Item description & Construct \\
\hline E1 & It is easy for me to remember how to perform transactions using a cardless cash interface & Perceived Ease of Use (EOU) \\
E2 & My interaction with a cardless cash Interface is clear and understandable & \\
E3 & Learning to operate a cardless cash Interface is easy for me & Perceived Usefulness(P.U.) \\
U1 & Using the cardless cash interface enables me to withdraw cash more quickly & Security(SEC) \\
U2 & Cardless cash interface improves my performance of utilising banking services & \\
U3 & Using the cardless cash interface for my banking services increases my productivity & \\
S1 & I believe that my transaction details are not disclosed to others in any way through the cardless cash & \\
S2 & Interface & Trust (T.R.) \\
S3 & Interface & \\
T1 & Thelieve that my identification is verified while conducting transactions through the cardless cash & \\
T2 & The service provider is trustworthy & \\
T3 & The service provider keeps customer interests in mind & \\
T4 & The service provider provides support in case of glitches or mistakes &
\end{tabular}

accuracy. Since we have adapted the established scales for the constructs and established reliability and validity using confirmatory factor analysis, we calculated the mean values of the items belonging to the respective constructs. The unit of analysis here is the end-user. We split the dataset into two sets for testing the hypothesis and the model's accuracy, namely the training dataset and the validation dataset. The training dataset is the dataset where we are trying to fit the research model to the dataset and get the model estimates. Then, we validated the research model by applying the same to the validation dataset. One of the measures of the validity of the model is the accuracy. While assessing the influence of the same constructs on the preference of cardless cash over the Card, we used different classification techniques as the dependent variable is binary (categorical). We used the Classification Confusion Matrix (also called the Error Matrix) to determine the accuracy of the model (classification techniques) on the validation dataset. To choose an appropriate classification model, we also made use of a lift chart.

\section{Data analysis and interpretation}

\section{Principal component analysis}

For seeking consensus regarding the factor structure, the responses obtained for all the items of all the constructs were subjected to the principal components analysis (PCA) extraction method. The rotation method was Varimax with Kaiser Normalisation. Before performing the PCA, the suitability of the data for factor analysis was assessed. The Kaiser-Meyer-Olkin measure of sampling
Table 4 Factor structure and reliability measure

\begin{tabular}{lllll}
\hline Factors- $>$ & TR & EOU & SEC & USEF \\
\hline Coefficient alpha- & 0.860 & 0.865 & 0.783 & 0.852 \\
Factor loadings & & & & \\
T3 & 0.805 & & & \\
T2 & 0.778 & & & \\
T1 & 0.771 & & & \\
T4 & .0 .714 & & & \\
E2 & & 0.875 & & \\
E1 & & 0.842 & & \\
E3 & & 0.725 & & \\
S2 & & & 0.834 & \\
S1 & & & 0.802 & \\
S3 & & & 0.712 & \\
U2 & & & & 0.819 \\
U1 & & & & 0.786 \\
U3 & & & & 0.712 \\
\hline
\end{tabular}

adequacy (MSA) was 0.892 . This value exceeded the recommended value of 0.6. Further, Bartlett's Test of Sphericity reached statistical significance, supported the factorability of the correlation matrix. The same factor structure was obtained from this analysis, where the four factors obtained accounted for $74.23 \%$ of the variance, which is closer to the thumb rule of $70 \%$.

Further, the reliability of the factors was evaluated using Cronbach's Coefficient Alpha, and the calculated values were all above 0.7 , indicating a reliable measurement instrument. Table 4 shows the Factor structure, along with the reliability measure Coefficient, Alpha. 
Table 5 Model fit indices for the measurement model

\begin{tabular}{llc}
\hline Model fit indices & Recommended value & $\begin{array}{l}\text { Measure- } \\
\text { ment } \\
\text { model }\end{array}$ \\
\hline Chi-square to the degree of freedom ratio (CMIN/df) & Between 1 and 5 & 3.13 \\
The goodness of fit index (GFI) & 0.900 or above & 0.950 \\
The adjusted goodness of fit index (AGFI) & 0.800 or above & 0.923 \\
Normed fit index (NFI) & 0.900 or above & 0.951 \\
Comparative fit index (CFI) & 0.900 or above & 0.966 \\
Root mean square of error approximate (RMSEA) & 0.070 or below & 0.064 \\
\hline
\end{tabular}

Table 6 Composite reliability and average variance extracted

\begin{tabular}{lllll}
\hline & TR & EOU & SEC & USEF \\
\hline TR & $\mathbf{0 . 6 1 1}$ & & & \\
EOU & 0.305 & $\mathbf{0 . 6 9 4}$ & & \\
SEC & 0.327 & 0.280 & $\mathbf{0 . 5 6 1}$ & \\
USEF & 0.527 & 0.410 & 0.321 & $\mathbf{0 . 6 6 3}$ \\
$\begin{array}{l}\text { Composite reli- } \\
\text { ability }\end{array}$ & $\mathbf{0 . 8 6 2}$ & $\mathbf{0 . 8 7 1}$ & $\mathbf{0 . 7 9 2}$ & $\mathbf{0 . 8 5 5}$ \\
\hline
\end{tabular}

Results are significant at $1 \%$ level of significance

Diagonal elements are average variance extracted. Non-diagonal elements are square of the correlation coefficient between constructs

\section{Confirmatory factor analysis}

Following Hair et al. (1998), we carried out the confirmatory factor analysis (CFA) to examine the reliability and validity of the proposed constructs.

The Model Fit Indices were considered to assess the goodness of fit of the proposed measurement model. The details of the Model Fit Indices of the Measurement Model and the Recommended Values are presented in Table 5. The $\chi 2$ to $\mathrm{df}$ ratio (3.13) indicates an acceptable fit between the model and the sample data (Carmines \& Mciver, 1981). All the other Model fit indices reported here were either relatively close to the recommended values or adhering to the recommendations. This result suggests that the data collected from the respondents is aligned with the items reflected in the constructs.

Next, we assessed the validity of the constructs. Churchill (1979) had suggested that convergent and discriminant validities should be examined for construct validity. Therefore, we assessed convergent validity by examining composite reliability (C.R.) and average variance extracted (AVE) from the five constructs (Hair et al., 1998). The AVE measures the variance captured by the indicators relative to the measurement error. Table 6 indicates that our C.R. values of all the four constructs were from 0.792 to 0.871 and were well above the suggested minimum value of 0.70 (Hair et al., 1998).
Similarly, AVE values were all above 0.50 , providing further evidence of the convergent validity. AVE in each construct is higher than the square of the correlation coefficients between two constructs (Fornell and Larcker, 1981). This result provides evidence of the discriminant validity.

\section{Classification analysis}

We applied the three classification techniques, namely Random Forest, Binary Logistic Regression, and Support Vector Machine, to assess the hypothesis related to the preference on the training dataset. Random Forest is an ensemble bagging technique. Binary Logistics Regression is a statistical technique. On the other hand, Support Vector Machine is a Nonlinear Classification Technique that maps its inputs into higher dimensional space. Each of these techniques has its advantages and disadvantages and thereby are competing for techniques. According to the Variable Importance Chart (see Fig. 2), while applying Random Forest on the training dataset, we find that Perceived Usefulness has been the vital variable in Card and cardless transactions for cash withdrawal. However, we find that the Perceived Ease of Use has a higher impact on cardless transactions.

When we applied Binary Logistic Regression on the training dataset, we get the estimates in Table 7. We have calculated the estimates considering the dependent variable preference where the two levels are $1=$ Cardless Cash and $0=$ Card.

Here, the $\mathrm{P}$ value indicates that the Perceived Usefulness positively influences the cardless cash preference over the Card, while the impact of the other independent variables is not significant. Figure 3 clearly shows the influence of Perceived Usefulness on the likelihood of preferring cardless over the Card for withdrawing cash at the ATMs.

Finding consensus from the linear and nonlinear model, we can conclude that Perceived Usefulness is the most crucial variable in preference of the cardless over the Card for cash withdrawal at the ATMs.

However, since we are looking for the model, which gives us more accuracy than the explanation, we further tried to 


\section{Variable Importance}

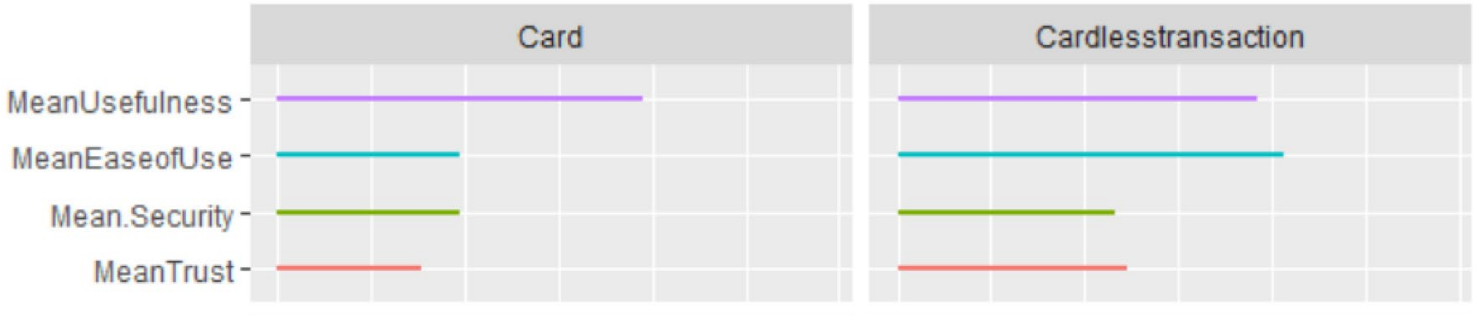

Fig. 2 Variable importance graph of random forest

Table 7 Results of binary logistic regression

\begin{tabular}{lcrl}
\hline Independent variables & Estimates & $\mathrm{z}$ value & $\mathrm{P}$ value \\
\hline Mean customer trust & -0.288 & -0.504 & 0.614391 \\
Mean perceived ease of use & 0.3323 & 0.773 & 0.439395 \\
Mean perceived usefulness & $\mathbf{1 . 2 3 4 5}$ & $\mathbf{4 . 0 7 2}$ & $\mathbf{0 . 0 0 0 0 4 6 7}$ \\
Mean perceived security & -0.3861 & -0.700 & 0.483866 \\
\hline
\end{tabular}

Results are significant at $1 \%$ level of significance validate the model on the validation data. We report the results in Table 8 .

From the comparison of accuracy with no information rate, we can reject the Binary Logistic Regression Model. Further, while comparing the other two models, Support Vector Machine is a clear winner in accuracy and sensitivity. The positive class is a cardless cash transaction. Further, this is validated by the lift chart in Fig. 4.

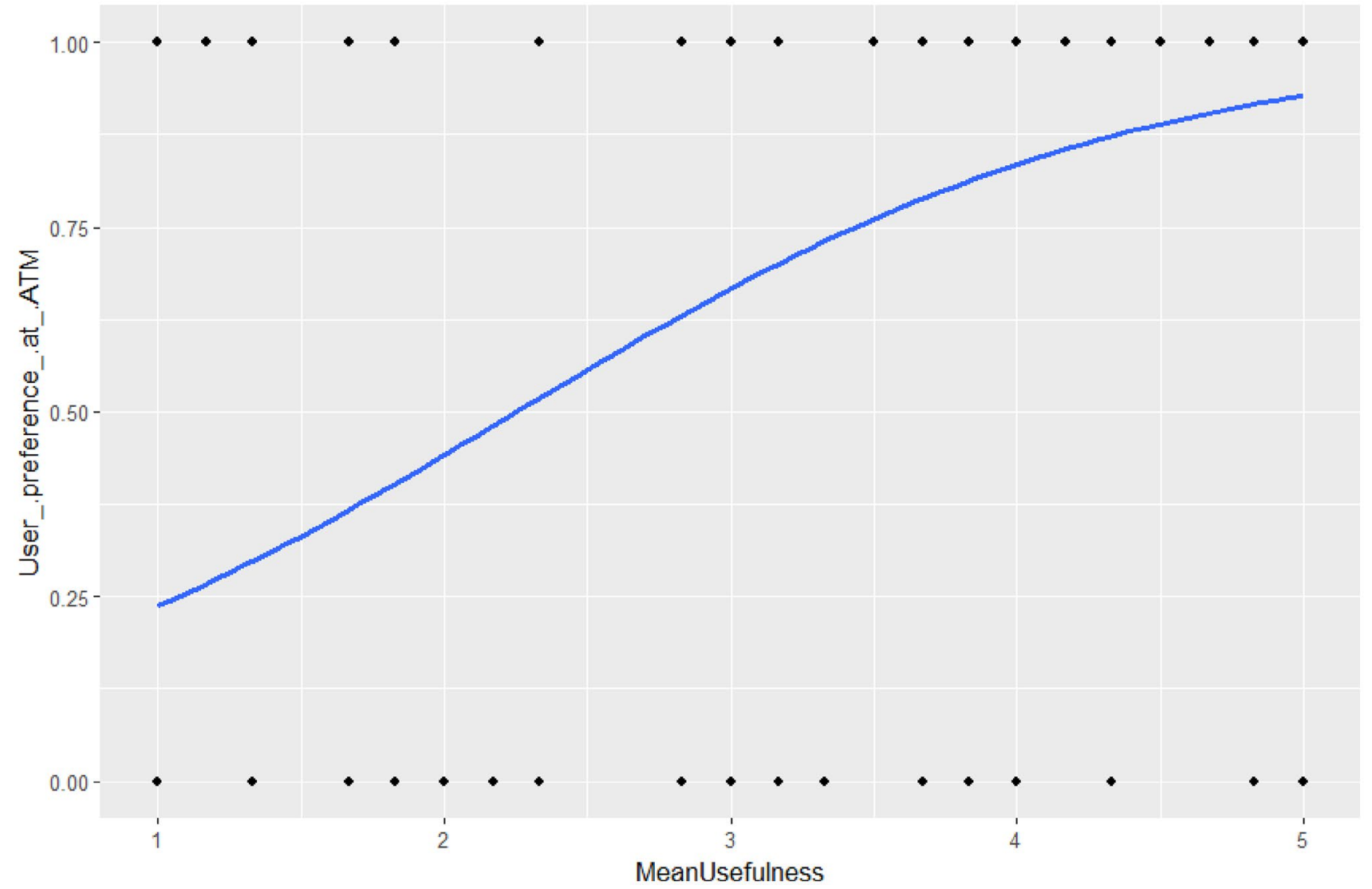

Fig. 3 Logistics model visualisation 
Table 8 Accuracy measures for various models

\begin{tabular}{llll}
\hline Criteria & $\begin{array}{l}\text { Random } \\
\text { forest (\%) }\end{array}$ & $\begin{array}{l}\text { Binary logistic } \\
\text { regression (\%) }\end{array}$ & $\begin{array}{l}\text { Support vec- } \\
\text { tor machine } \\
(\%)\end{array}$ \\
\hline Accuracy & 90.45 & 80.89 & 91.08 \\
Sensitivity & 98.44 & 94.53 & 100 \\
Specificity & 55.17 & 20.67 & 51.72 \\
No information rate & 81.53 & & \\
\hline
\end{tabular}

that the availability of an ATM in convenient locations was a dominant factor affecting customers choosing a bank in their respective countries. In research by Tuli et al. (2012), it was found that the critical factor influencing the usage of ATM services by customers is the ease of use and ATM's availability. Yet again, various studies examined the impact of customer perception on their satisfaction (Samudra \& Phadtare, 2012; Venkatesh \& Davis, 2000, Thakur, 2013), and customers' intend to use technology (Udo \& Bagchi, 2010; Alawan et al. 2017; Komaik \& Benbasat, 2006). How-

Fig. 4 Lift chart

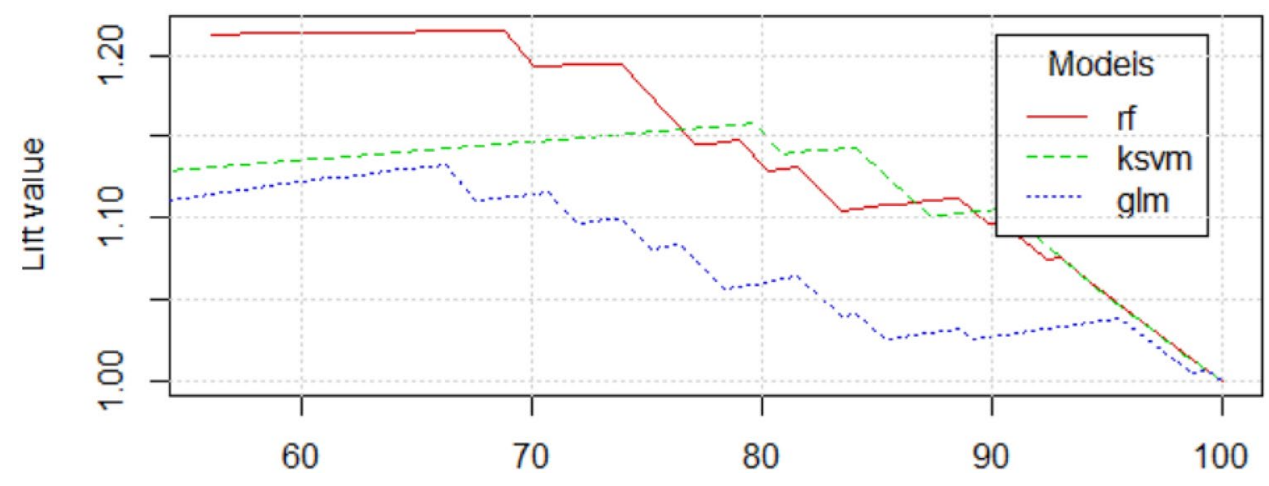

The lift value was consistently above 1 for most proportion of the validation data corresponding to the Support Vector Machine Model (SVM) compared to the Random Forest (R.F.) and Binary Logistic Regression Model (BLM).

The bottom line of the Classification analysis after making inference from the different models applied, only hypothesis $H 1$ stands out to be significant, which is the positive influence of Perceived Usefulness on the preference of Cardless Cash interface over Card. While not undermining the importance of the other factors in the accuracy of the classification model, Perceived Usefulness has been a relatively more important factor in influencing the preference.

\section{Discussion}

This study is about the customer preference towards using cardless over Card at the ATMs for withdrawing cash. ATMs usage grew over the years mainly due to the regulatory changes concerning financial inclusion, which increased the penetration of banks and white label ATMs. According to the ATM statistics for January 2020, released by the Reserve Bank of India, 112,944 ATMs operate. The number of credit card transactions via ATMs was 854,729, and debit card use was 667,711,316 (RBI, 2020). In modern life, where money plays a vital role in life, ATMs help people get money whenever they need it, even in emergencies (Pandian \& Sharma, 2012). Again, in previous studies by Ulengin B (1998) in Turkey and Almossawi (2001) in Bahrain, it was concluded
Table 9 Usage behaviour in the financial year 2018-19 at ATMs ( Source: RBI)

\begin{tabular}{lcccc}
\hline ATM & Volume(mn) & Value (Rs bn) & $\begin{array}{l}\text { Share- } \\
\text { volume } \\
(\%)\end{array}$ & $\begin{array}{l}\text { Share-value } \\
(\%)\end{array}$ \\
\hline Credit cards & 9.77 & 45.33 & 0.10 & 0.14 \\
Debit cards & 9859.61 & $33,107.89$ & 99.90 & 99.86 \\
\hline
\end{tabular}

ever, few studies have integrated customer preference to use technology, especially in the Indian context. Therefore, this study is unique. It discusses the association of customers' perception of ease of use, usefulness, security, and trust influencing cardless technology preference over a card at ATMs in India.

This study can be termed highly contextual as the nation is moving rapidly into digital transformation. RBI reports that India is second only to China in the queue regarding the number of debit cards issued. Specifically, banks in India issued 63 per cent higher debit cards in 2019 than in 2015. The usage behaviour at ATMs in the financial year 2018-19 concerning debit and credit cards is depicted in Table 9 below:

There have been earlier innovations (such as Instant Money Transfer, M-Pesa, Pockets App, and Mobile Money). Yet, the concept of 'cardless' technology was introduced in 2014 when RBI announced that they were working on a new system that would allow users to send money via SMS that 
could be withdrawn from any ATM, even if the recipient does not have a bank account. Nowadays, most banks are seen communicating this feature through their website and mobile apps.

As seen in the literature, customers' preference has an immense impact on using any product or service. Customer preference is a propensity towards a product/service (Lazzi et al., 2016) due to product characteristics (such as price and quality) or the person's characteristics (goal, attitude, or income) (Ghose \& Lowengart, 2013). A study by Ahn \& Park (2012) states that there are two key components to make decision-making efficient and effective, which is eliciting customer preference and matching the preference with product profiles. Again, another study by Dong (2009) found customer preference significant in the context of emerging technology. However, unlike these studies, in this study, we find that there is the only factor affecting customer preference towards using cardless technology, which is the perceived usefulness. Though perceived security and customer trust are often assumed to impact the preference of cardless technology positively, on the contrary, customers find security and trust a deep concern while using physical cards at ATMs as they are vulnerable to fraud and cloning. Therefore, banks do not have to educate customers about the potential risks or security implications of the cardless technology, build trust or communicate the ease with which customers can use it. Banks need to understand and discover the scenarios in which the cardless cash feature is more useful to customers and beneficial and communicate those.

\section{Conclusion}

\section{Contribution of the study}

Based on the discussion, we may infer that the possibility of adopting cardless technology can revolutionise how the customers will access cash, forbidding the need for a physical card. Although ATM operations have played a significant contributory factor in fundamentally enhancing the customer relationship with access to cash and enabling payments in the bank, their frequent usage has made them vulnerable to network breaches. This state has affected customer expectations towards banking operations vis-à-vis security and trust. However, ATMs with cardless technology can provide a more robust authentication process to ensure the right person accesses an account eliminating the risk of spying on the user of a cash-dispensing machine and card-skimming that customers may encounter. It also prevents critical payment data from being inserted into physical transaction points and ensures that customer data are never stored on the mobile facilities the customer is transacting on. Hence, it is perceived by customers as secured compared to using a physical card. This study reveals something fascinating: the influence of usefulness alone on the likelihood of preferring cardless cash technology over Card is very significant as far as the implications of this study are in the banking industry.

The banking system in India has advanced well in terms of technology, and customers seldom doubt the products and services. This phenomenon could also be the reason that the concern regarding trust and security seems irrelevant. Again, the boom in the mobile economy is such that mobiles and smartphones have become rampant in the Indian context. The ease of use of mobile and smartphone-based technology is insignificant for customers in India. Hence, banks need not be concerned about the security perceptions or the trust aspect regarding the technology. Customers have no issues regarding the ease of using cardless technology as it requires just a mobile device and the application to transfer or withdraw cash. The only concern customers perceive how this technology can be useful compared to the existing cardbased cash withdrawals. Banks thus have to append how to communicate and educate customers about its usefulness to its customers.

\section{Future research directions and limitations}

Future research should attempt to expand the sample group to include digital banking customers and determine if digital banking customers would use cardless technology and possible reasons they would not. A two-stage cluster and stratified sampling may be used to profile the customers based on their preferences and analyse the influencing factors in future research. A possible increase in the sample size with respondents from diverse demography, especially education levels, may add value to the results.

To conclude, the cardless technology currently enables customers to enter a code obtained via SMS and withdraw a predefined amount of cash from ATMs. Yet, they are a significant milestone towards a future that removes all the banking world's physical instruments.

Funding Open access funding provided by Manipal Academy of Higher Education, Manipal.

\section{Declarations}

Conflict of interest On behalf of all authors, the corresponding author states that there is no conflict of interest.

Open Access This article is licensed under a Creative Commons Attribution 4.0 International License, which permits use, sharing, adaptation, distribution and reproduction in any medium or format, as long as you give appropriate credit to the original author(s) and the source, provide a link to the Creative Commons licence, and indicate if changes were made. The images or other third party material in this article are 
included in the article's Creative Commons licence, unless indicated otherwise in a credit line to the material. If material is not included in the article's Creative Commons licence and your intended use is not permitted by statutory regulation or exceeds the permitted use, you will need to obtain permission directly from the copyright holder. To view a copy of this licence, visit http://creativecommons.org/licenses/by/4.0/.

\section{References}

Agidi, R.C. 2018. Biometrics: The future of banking and financial service industry in Nigeria. International Journal of Electronics and Information Engineering 9 (2): 91-105.

Ahn, H.J., and S. Park. 2012. How does customer's product expertise moderate the usefulness of information recommendation agents in online stores? Information Research 17 (4): 550.

Alalwan, A.A., Y.K. Dwivedi, and N.P. Rana. 2017. Factors influencing adoption of mobile banking by Jordanian bank customers: Extending UTAUT2 with trust. International Journal of Information Management 37 (3): 99-110.

Ali, Q., S. Parveen, H. Yaacob, and Z. Zaini. 2021. Cardless banking system in Malaysia: An extended TAM. Risks 9 (2): 41.

Almossawi, M. 2001. Bank selection criteria employed by college students in Bahrain: An empirical analysis. International Journal of Bank Marketing 19 (3): 115-125.

Amin, H. 2008. Factors affecting the intentions of customers in Malaysia to use mobile phone credit cards. Management Research News 31 (7): 493-503.

Amin, H., and T. Ramayah. 2010. SMS banking: Explaining the effects of attitude, social norms and perceived security and privacy. The Electronic Journal of Information Systems in Developing Countries 41 (1): 1-15.

Amin, H., R. Supinah, M.M. Aris, and R. Baba. 1970. Receptiveness of mobile banking by Malaysian local customers in Sabah: An empirical investigation. The Journal of Internet Banking and Commerce 17 (1): 1-12.

Amin, M., S. Rezaei, and M. Abolghasemi. 2014. User satisfaction with mobile websites: the impact of perceived usefulness (P.U.), perceived ease of use (PEOU) and trust. Nankai Business Review International 5 (3): 258-274.

Anderson, J.C., and D.W. Gerbing. 1988. Structural equation modeling in practice: A review and recommended two-step approach. Psychological Bulletin 103 (3): 411.

Arnoud, W., A. Boot, and M. Matej. 2011. Financial innovations, marketability and stability in banking. University of Amsterdam, ACLE and CEPR and University of Ljubljana and ACLE.

Asfour, H.K., and S.I. Haddad. 2014. The impact of Mobile Banking on enhancing customers' E-satisfaction: An empirical study on commercial banks in Jordan. International Business Research 7 (10): 145

Au, Y.A., and R.J. Kauffman. 2008. The economics of mobile payments: Understanding stakeholder issues for an emerging financial technology application. Electronic Commerce Research and Applications 7 (2): 141-164.

Auer, R., Cornelli, G. \& Frost, J.(2020). Covid-19, cash, and the future of payments. BIS Bulettin. https://www.bis.org/publ/ bisbullo3.pdf

Bahillo, J. A., Ganguly, S., \& Kremer, A. (2016). The value in digitally transforming credit risk management. McKinsey Global Institute.

Bankole, F.O., O.O. Bankole, and I. Brown. 2011. Mobile banking adoption in Nigeria. The Electronic Journal of Information Systems in Developing Countries 47 (1): 1-23.
Bansal, G., and F.M. Zahedi. 2014. Trust-discount tradeoff in three contexts: Frugality moderating privacy and security concerns. Journal of Computer Information Systems 55 (1): 13-29.

Bátiz-Lazo, B., Efthymiou, L., \& Michael, S. (2016). Milestones for a global cashless economy. In The Book of Payments (pp. 391401). Palgrave Macmillan, London.

Bhakta, P.(2017). Demonetisation effect: Digital payments India's new currency; debit card transactions surge to over 1 billion. https:// economictimes.indiatimes.com/industry/banking/finance/banki ng/digital-payments-indias-new-currency-debit-card-transactio ns-surge-to-over-1-billion/articleshow/58863652.cms?utm source $=$ contentofinterest\&utm_medium $=$ text\&utm_campaign $=$ cppst

Bhosale, S.T., and B.S. Sawant. 2012. Security in e-banking via card less biometric ATMs. International Journal of Advanced Technology \& Engineering Research 2 (4): 457-462.

Bhosale, S.T., and B.S. Sawant. 2012. Security in e-banking via card less biometric ATMs. International Journal of Advanced Technology \& Engineering Research 2 (4): 457-462.

Bitner, M.J., S.W. Brown, and M.L. Meuter. 2000. Technology infusion in service encounters. Journal of the Academy of Marketing Science 28 (1): 138-149.

Brown, S.A., and V. Venkatesh. 2005. Model of adoption of technology in households: A baseline model test and extension incorporating household life cycle. MIS Quarterly 29: 399-426.

Capgemini. (2013).Trends in the Global Banking Industry. https:// www.capgemini.com/wp-content/uploads/2017/07/trends_in_ the_global_banking_industry_2013.pdf

Chatterjee, D., and K. Bolar. 2019. Determinants of mobile wallet intentions to use: The mental cost perspective. International Journal of Human-Computer Interaction 35 (10): 859-869.

Chen, Y.M., T.H. Hsu, and Y.J. Lu. 2018. Impact of flow on mobile shopping intention. Journal of Retailing and Consumer Services 41: 281-287.

Chen, Y., and F.M. Zahedi. 2016. Individuals' internet security perceptions and behaviors: Polycontextual contrasts between the United States and China. Mis Quarterly 40 (1): 205-222.

Chitungo, S. K., \& Munongo, S. (2013). Extending the technology acceptance model to mobile banking adoption in rural Zimbabwe. Journal of business administration and education, 3(1).

Churchill, G.A., Jr. 1979. A paradigm for developing better measures of marketing constructs. Journal of Marketing Research 16 (1): 64-73.

David-West, O. 2016. The path to digital financial inclusion in Nigeria: Experiences of Firstmonie. Journal of Payments Strategy \& Systems 9 (4): 256-273.

Davis, F.D. 1989. Perceived usefulness, perceived ease of use, and user acceptance of information technology. MIS Quarterly 13: 319-340.

Deloitte. (2015). Strategies for optimising your cash management. https://www2.deloitte.com/content/dam/Deloitte/ca/Docum ents/finance/ca-en-FA-strategies-for-optimizing-your-cashmanagement.pdf

Doll, W.J., A. Hendrickson, and X. Deng. 1998. Using Davis's perceived usefulness and ease-of-use instruments for decision making: A confirmatory and multigroup invariance analysis. Decision Sciences 29 (4): 839-869.

Dong, B. 2015. How a customer participates matters: "I am producing" versus "I am designing." Journal of Services Marketing 29 (4): 498-510

Dwyer, F.R., P.H. Schurr, and S. Oh. 1987. Developing buyer-seller relationships. Journal of Marketing 51 (2): 11-27.

Eriksson, K., K. Kerem, and D. Nilsson. 2005. Customer acceptance of internet banking in Estonia. International Journal of Bank Marketing 23 (2): 200-216. 
Festinger, L. (1957). A theory of cognitive dissonance (Vol. 2). Stanford university press.

Finserv. (2016). Cardless ATMs - The Evolution of Cash Access. https://www.fiserv.com/en/about-fiserv/resource-center/whitepapers/cardless-atms-the-evolution-of-cash-access.html

Flavián, C., M. Guinaliu, and E. Torres. 2006. How bricks-andmortar attributes affect online banking adoption. International Journal of Bank Marketin 24 (6): 406-423.

Fogliatto, F.S., G.J. Da Silveira, and D. Borenstein. 2012. The mass customisation decade: An updated review of the literature. International Journal of Production Economics 138 (1): 14-25.

Fornell, C., and D.F. Larcker. 1981. Evaluating structural equation models with unobservable variables and measurement error. Journal of Marketing Research 18 (1): 39-50.

Franke, N., P. Keinz, and C.J. Steger. 2009. Testing the value of customisation: When do customers really prefer products tailored to their preferences? Journal of Marketing 73 (5): 103-121.

Gefen, D., E. Karahanna, and D.W. Straub. 2003. Trust and TAM in online shopping: An integrated model. MIS Quarterly 27: 51-90.

Ghose, S., and O. Lowengart. 2013. Consumer choice and preference for brand categories. Journal of Marketing Analytics 1 (1): 3-17.

Glavee-Geo, R., A.A. Shaikh, and H. Karjaluoto. 2017. Mobile banking services adoption in Pakistan: Are there gender differences? International Journal of Bank Marketing 35 (7): 1090-1114.

Gomber, P., J.A. Koch, and M. Siering. 2017. Digital Finance and FinTech: Current research and future research directions. Journal of Business Economics 87 (5): 537-580.

Gomber, P., R.J. Kauffman, C. Parker, and B.W. Weber. 2018. On the fintech revolution: Interpreting the forces of innovation, disruption, and transformation in financial services. Journal of Management Information Systems 35 (1): 220-265.

Guo, Y., and C. Liang. 2016. Blockchain application and outlook in the banking industry. Financial Innovation 2 (1): 1-12.

Guritno, S., and H. Siringoringo. 2013. Perceived usefulness, ease of use, and attitude towards online shopping usefulness towards online airlines ticket purchase. Procedia-Social and Behavioral Sciences 81: 212-216.

Hair, H.F., R.E. Anderson, R.L. Tatham, and W.C. Black. 1998. Multivariate data analysis. London: Prentice-Hall.

Hampshire, C. 2017. A mixed methods empirical exploration of U.K. consumer perceptions of trust, risk and usefulness of mobile payments. International Journal of Bank Marketing 35 (3): 354-369.

Hanafizadeh, P., B.W. Keating, and H.R. Khedmatgozar. 2014. A systematic review of Internet banking adoption. Telematics and Informatics 31 (3): 492-510.

Howard, J.A., and J.N. Sheth. 1969. The theory of buyer behaviour. London: Wiley.

Iazzi, A., D. Vrontis, O. Trio, and Y. Melanthiou. 2016. The motives and benefits of using customer experience led differentiators in the re-launching of a failed product a case study of cranes \& components (P) Ltd. Journal of Transnational Management 21 (2): 84-89.

Rustom Irani. (2021). RBI hikes fee banks pay for use of other lenders' ATMs http://timesofindia.indiatimes.com/articleshow/83414639. cms?utm_source $=$ contentofinterest\&utm_medium $=$ text\&utm campaign $=$ cppst.

Istrate, C.M. 2014. Cardless withdrawal system for mobile banking applications. Journal of Mobile, Embedded and Distributed Systems 6 (1): 11-16.

Jayasingh, S., \& Eze, U. C. (2009). Exploring the factors affecting the acceptance of mobile coupons in Malaysia. In 2009 Eighth International Conference on Mobile Business (pp. 329-334). IEEE.
Johnson, R. (2014). Cardless cash: The future of ATMs? https://www.ncr.com/company/blogs/financial/cardl ess-cash-the-future-of-atms

Kaka, N., Madgavkar, A., Kshirsagar, A., Gupta, R., Manyika J., Bahl, K., \& Gupta, S. (2019). Digital India: Technology to transform a connected nation. Mckinsey Global Institute.

Karthikeyan, R.S. (2013). Mobile Payments-A Comparative study between European and Non-European Market.

King, W.R., and J. He. 2006. A meta-analysis of the technology acceptance model. Information \& Management 43 (6): 740-755.

Kinsman, J.E. 2019. Cardless banking in the Nelson Mandela Metropole: A means of financial inclusion for the excluded. Journal of Economic and Financial Sciences 12 (1): 1-11.

Komiak, S.Y., and I. Benbasat. 2006. The effects of personalization and familiarity on trust and adoption of recommendation agents. MIS Quarterly 30: 941-960.

KPMG. (2018). Eliminating Friction in Financial Services Path to Purchase. https://assets.kpmg/content/dam/kpmg/in/pdf/2018/ 09/consumer-eliminating-friction-financial-services.pdf

Kumar, K.N., and P.R. Balaramachandran. 2018. Robotic process automation-a study of the impact on customer experience in retail banking industry. Journal of Internet Banking and Commerce 23 (3): 1-27.

Lee, T., and J. Jun. 2007. Contextual perceived value?: Investigating the role of contextual marketing for customer relationship management in a mobile commerce context. Business Process Management Journal 13 (6): 798-814.

Lee, Y.H., Y.C. Hsieh, and C.N. Hsu. 2011. Adding innovation diffusion theory to the technology acceptance model: Supporting employees' intentions to use e-learning systems. Journal of Educational Technology \& Society 14 (4): 124-137.

Legris, P., J. Ingham, and P. Collerette. 2003. Why do people use information technology? A critical review of the technology acceptance model. Information \& Management 40 (3): 191-204.

Lewin, K. 1951. Intention, will and need. In Organization and pathology of thought: Selected sources, ed. D. Rapaport, 95-153. Columbia: Columbia University Press.

Liébana-Cabanillas, F., V. Marinković, and Z. Kalinić. 2017. A SEMneural network approach for predicting antecedents of m-commerce acceptance. International Journal of Information Management 37 (2): 14-24.

Lim, C.Y., M. Woods, C. Humphrey, and J.L. Seow. 2017. The paradoxes of risk management in the banking sector. The British Accounting Review 49 (1): 75-90.

Mann, B.J.S., and S.K. Sahni. 2013. Role of trust and customer loyalty in reducing perceived security risk in internet banking. International Journal of Electronic Business 10 (4): 331-354.

Marlin, S. 1998. Q\&A executive: Halt payment proliferation. Bank Systems and Technology 35: 42-43.

Mastercard, Empays Payment join hands for contact-free ATM cash withdrawals. 2020.https://bfsi.economictimes.indiatimes.com/ news/financial-services/mastercard-empays-payment-join-handsfor-contact-free-atm-cash-withdrawals/76284483

Mattila, A., and M. Mattila. 2005. How perceived security appears in the commercialisation of internet banking. International Journal of Financial Services Management 1 (1): 89-101.

Mayer, R.C., J.H. Davis, and F.D. Schoorman. 1995. An integrative model of organisational trust. Academy of Management Review 20 (3): 709-734.

Mbama, C.I., and P.O. Ezepue. 2018. Digital banking, customer experience and bank financial performance. International Journal of Bank Marketing 36 (2): 230-255.

McIver, J., and E.G. Carmines. 1981. Unidimensional scaling, vol. 24. London: Sage. 
Mehrad, D., and S. Mohammadi. 2017. Word of Mouth impact on the adoption of mobile banking in Iran. Telematics and Informatics 34 (7): 1351-1363.

Mercandante, K. (2020). The future of cash - Will it Dissappear or Become Obsolete? https://www.moneyunder30.com/ what-is-the-future-of-cash

Mohite, V., Shikhare, R., Kharde, S., \& Sarangdhar, P. (2021). Digital Payment Saga: Pandemic Impact on ATM Usage in India (No. 5771). EasyChair.

Moodley, T., and I. Govender. 2016. Factors influencing academic use of internet banking services: An empirical study. African Journal of Science, Technology, Innovation and Development 8 (1): 43-51.

Moodley-Isaacs, N. (2011). Use your cellphone to draw cash. http:// www.iol.co.za/personal-finance/my-money/banking/use-yourcellphone-to-draw-cash-1062775

Moon, H., and H.H. Lee. 2014. Consumers' preference fit and ability to express preferences in the use of online mass customisation. Journal of Research in Interactive Marketing 8 (2): 124-143.

Moser, F. 2015. Mobile Banking: A fashionable concept or an institutionalised channel in future retail banking? Analysing patterns in the practical and academic mobile banking literature. International Journal of Bank Marketing 33 (2): 162-177.

KPMG \& NASSCOM. (2016). Fintech in India. https://assets.kpmg/ content $/ \mathrm{dam} / \mathrm{kpmg} / \mathrm{pdf} / 2016 / 06 /$ FinTech-new.pdf

Ngumi, P. M. (2014). Effect of bank innovations on financial performance of commercial banks in Kenya (Doctoral dissertation).

Pandian, V., and R. Sharma. 2012. A study of customer's attitude towards ATM services of banks in Rajapalayam, Tamil Nadu. International Journal of Reserach in Finance and Marketing 2 (3): $38-56$.

Phothikitti, K. (2020). Factors influencing intentions to use cardless automatic teller machine (ATM).

Poong, Y.S., S. Yamaguchi, and J.I. Takada. 2017. Investigating the drivers of mobile learning acceptance among young adults in the World Heritage town of Luang Prabang, Laos. Information Development 33 (1): 57-71.

Prelec, D., and G. Loewenstein. 1998. The red and the black: Mental accounting of savings and debt. Marketing Science 17: 4-28.

Ramayah, T., and N.M. Suki. 2006. Intention to use mobile P.C. among MBA students: implications for technology integration in the learning curriculum. UNITAR e-Journal 2 (2): 30-39.

Raza, S.A., A. Umer, and N. Shah. 2017. New determinants of ease of use and perceived usefulness for mobile banking adoption. International Journal of Electronic Customer Relationship Management 11 (1): 44-65.

Reichheld, F.F., and P. Schefter. 2000. E-loyalty: Your secret weapon on the web. Harvard Business Review 78 (4): 105-113.

Rempel, J.K., J.G. Holmes, and M.P. Zanna. 1985. Trust in close relationships. Journal of Personality and Social Psychology 49 (1): 95.

Researve Bank of India. (2020). Assessment of the progress of digitisation from cash to electronic. https://www.rbi.org.in/Scripts/Publi cationsView.aspx?id=19417

Reserve Bank of India . (2019). Report of the Committee to Review the ATM Interchange Fee Structure. https://m.rbi.org.in/Scripts/ PublicationReportDetails.aspx?UrlPage $=\& I D=1000 \# 2$

Salimon, M.G., R.Z.B. Yusoff, and S.S.M. Mokhtar. 2017. The mediating role of hedonic motivation on the relationship between adoption of e-banking and its determinants. International Journal of Bank Marketing 35 (4): 558-582.

Samudra, M.S., and M. Phadtare. 2012. Factors influencing the adoption of mobile banking with special reference to Pune City. ASCI Journal of Management 42 (1): 51-65.

Shaikh, A.A., and H. Karjaluoto. 2015. Mobile banking adoption: A literature review. Telematics and Informatics 32 (1): 129-142.
Shaw, N. 2014. The mediating influence of trust in the adoption of the mobile wallet. Journal of Retailing and Consumer Services 21 (4): 449-459.

Shell, M. A., \& Buell, R. W. (2019). Mitigating the negative effects of customer anxiety through access to human contact. Harvard Business School Technology \& Operations Mgt. Unit Working Paper, (19-089).

Shen, Y.C., C.Y. Huang, C.H. Chu, and C.T. Hsu. 2010. A benefitcost perspective of the consumer adoption of the mobile banking system. Behaviour \& Information Technology 29 (5): 497-511.

Simonson, I. 2005. Determinants of customers' responses to customised offers: Conceptual framework and research propositions. Journal of Marketing 69 (1): 32-45.

Singh, S., and R. Rana. 2017. Study of consumer perception of digital payment mode. Journal of Internet Banking and Commerce 22 (3): $1-14$.

Singh, S., and R.K. Srivastava. 2020. Understanding the intention to use mobile banking by existing online banking customers: An empirical study. Journal of Financial Services Marketing 25 (3): 86-96.

Soman, D. 2003. The effect of payment transparency on consumption: Quasi-experiments from the field. Marketing Letters 14 (3): $173-183$

Sundarraj, R.P., and J. Wu. 2005. Using information-systems constructs to study online-and telephone-banking technologies. Electronic Commerce Research and Applications 4 (4): 427-443.

Tang, J.T.E., T.I. Tang, and C.H. Chiang. 2014. Blog learning: Effects of users' usefulness and efficiency towards continuance intention. Behaviour \& Information Technology 33 (1): 36-50.

Teoh, W.M.Y., S.C. Chong, B. Lin, and J.W. Chua. 2013. Factors affecting consumers' perception of electronic payment: An empirical analysis. Internet Research 23 (4): 465-485.

Thakur, R. 2013. Customer adoption of mobile payment services by professionals across two cities in India: An empirical study using modified technology acceptance model. Business Perspectives and Research 1 (2): 17-30.

Tuli, R., A. Khatri, and A. Yadav. 2012. A comparative study of customer attitude towards ATM of SBI and ICICI bank. International Journals of Marketing and Technology 2 (8): 463-475.

Udo, G.J., K.K. Bagchi, and P.J. Kirs. 2010. An assessment of customers'e-service quality perception, satisfaction and intention. International Journal of Information Management 30 (6): 481-492.

Ülengin, B. 1998. Using hierarchical information integration to examine customer preferences in banking. International Journal of Bank Marketing 16 (5): 202-210.

Value of currency in circulation in India from F.Y. 2015 to F.Y. 2021. https://www.statista.com/statistics/1028099/india-currency-incirculation-value/

Venkatesh, V., and M.G. Morris. 2000. Why don't men ever stop to ask for directions? Gender, social influence, and their role in technology acceptance and usage behavior. MIS Quarterly 24: 115-139.

Venkatesh, V., and F.D. Davis. 2000. A theoretical extension of the technology acceptance model: Four longitudinal field studies. Management Science 46 (2): 186-204.

Venkatesh, V., and F.D. Davis. 2000. A theoretical extension of the technology acceptance model: Four longitudinal field studies. Management Science 46 (2): 186-204.

Wang, Y.S., Y.M. Wang, H.H. Lin, and T.I. Tang. 2003. Determinants of user acceptance of Internet banking: An empirical study. International Journal of Service Industry Management 14 (5): 501-519.

World Cash Report. 2018. https://www.g4scashreport.com/-/media/ $\mathrm{g} 4 \mathrm{~s} /$ cash-report/files/2018-world-cash-report---english.ashx?la= en\&hash=0F3BECD46B4820D7FA32112E99252AAB 
Yap, K., Wong, D. H., \& Bak, L. R. (2009). Building Trust in e-banking: Where is the Line between Online and Offline Banking? Australian \& New Zealand Marketing Academy Conference (ANZMAC) 2009, 30 November - 2 December 2009, Melbourne, VIC,

Yiu, C.S., K. Grant, and D. Edgar. 2007. Factors affecting the adoption of Internet Banking in Hong Kong-implications for the banking sector. International Journal of Information Management 27 (5): 336-351.

Yousafzai, S.Y., G.R. Foxall, and J.G. Pallister. 2007. Technology acceptance: A meta-analysis of the TAM: Part 1. Journal of Modelling in Management 2 (3): 251-280.

Yousefi, N., and A. Nasiripour. 2015. A proposed model of e-trust for electronic banking. Management Science Letters 5 (11): $1029-1040$.

Zachariadis, M., \& Ozcan, P. (2017). The API economy and digital transformation in financial services: The case of open banking.

Zhou, T. 2011. Examining the critical success factors of mobile website adoption. Online Information Review 35 (4): 636-652.

Publisher's Note Springer Nature remains neutral with regard to jurisdictional claims in published maps and institutional affiliations.
Bindu K. Nambiar currently serves as Faculty (Marketing) at SBIs Apex Training Institute, State Bank Institute of Consumer Banking, Hyderabad. She holds a PhD in Management Studies and MBA in marketing. Her research areas of interest include customer relationship management in the services sector, consumer behaviour in retail marketing, branding for locally manufactured/homegrown products and sustainability in business using societal marketing.

Kartikeya Bolar is an Associate Professor of Operations and Decision Sciences area at T A Pai Management Institute, Manipal Academy of Higher Education. He holds a PhD in Technology Management, MBA in Information Systems and a degree in Computer Engineering. He has been actively involving in digital learning and virtual teaching space. His research interests are in the field of E-Commerce Diffusion, Digital learning, Data Mining, Data Science, Business Analytics and Technology Adoption. 